\title{
Extractability and characteristics of proteins deriving from wheat DDGS
}

Article

Accepted Version

Chatzifragkou, A., Prabhakumari, P. C., Kosik, O., Lovegrove, A., Shewry, P. R. and Charalampopoulos, D. (2016)

Extractability and characteristics of proteins deriving from wheat DDGS. Food Chemistry, 198. pp. 12-19. ISSN 03088146 doi: https://doi.org/10.1016/j.foodchem.2015.11.036 Available at https://centaur.reading.ac.uk/46416/

It is advisable to refer to the publisher's version if you intend to cite from the work. See Guidance on citing.

To link to this article DOI: http://dx.doi.org/10.1016/j.foodchem.2015.11.036

Publisher: Elsevier

All outputs in CentAUR are protected by Intellectual Property Rights law, including copyright law. Copyright and IPR is retained by the creators or other copyright holders. Terms and conditions for use of this material are defined in the End User Agreement.

\section{www.reading.ac.uk/centaur}

\section{CentAUR}

Central Archive at the University of Reading 
Reading's research outputs online 
1 Extractability and characteristics of proteins deriving from wheat

3 Afroditi Chatzifragkou ${ }^{1}$, Parvathy Chandran Prabhakumari ${ }^{1}$, Ondrej Kosik ${ }^{2}$, Alison

$5{ }^{1}$ Department of Food and Nutritional Sciences, University of Reading, Whiteknights, 
13 Wheat Distillers' Dried Grains with Solubles (DDGS) and in-process samples were

14 used for protein extraction. Prolamins were the predominant protein components in

15 the samples. The absence of extractable $\alpha$ - and $\gamma$-gliadins in DDGS indicated protein 16 aggregation during the drum drying processing stage. Prolamin extraction was 17 performed using $70 \%(\mathrm{v} / \mathrm{v})$ ethanol or alkaline-ethanol solution in the presence of 18 reducing agent. DDGS extracts had relatively low protein contents (14-44.9\%, w/w), 19 regardless of the condition applied. The wet solids were the most suitable raw 20 material for protein extraction, with recovery yields of $\sim 55 \%(\mathrm{w} / \mathrm{w})$ and protein 21 content of $\sim 58 \%(\mathrm{w} / \mathrm{w})$ in $70 \%(\mathrm{v} / \mathrm{v})$ ethanol. Protein extracts from wet solids were 22 significantly rich in glutamic acid and proline. Mass balance calculations 23 demonstrated the high carbohydrate content $(\sim 50 \%, \mathrm{w} / \mathrm{w})$ of solid residues. Overall, 24 the feasibility of utilising in-process samples of DDGS for protein extraction with 25 commercial potential was demonstrated.

26 Keywords: DDGS, protein, wheat, distillery, extraction, in-process samples, amino 27 acids 


\section{Introduction}

Distillers' Dried Grains with Solubles (DDGS) is the principal by-product of the drygrind distillation process, generated mainly from beverage alcohol plants (e.g. whisky and neutral spirits distilleries) or from grain-based fuel-ethanol plants. In the case of distilleries, single or blended grains including wheat, barley, maize and rye can be utilised as feedstock, whereas fuel-ethanol plants use either corn (maize) (US) or wheat (Europe) as starting materials.

During the dry-grind process, in the case of bioethanol production, whole grains are milled and liquefied, followed by the addition of amylolytic enzymes for starch conversion into fermentable glucose. In distillery plants, saccharification of the milled grain is carried out using malted barley instead of external enzymes and a food-grade process is followed, as the end-product (potable ethanol) is intended for human consumption. For both bioethanol and potable ethanol production, yeast is added to ferment the sugars into ethanol and carbon dioxide. At the end of the fermentation, the whole stillage undergoes distillation by direct steam injection. Ethanol is further purified via dehydration, whereas the non-volatile components (spent solids) are centrifuged to produce a liquid fraction (thin stillage) and a solid fraction (wet solids). Around $15 \%$ or more of the thin stillage is recycled to the liquefaction process of the ground grain, whereas the remaining is concentrated in a series of steam driven evaporators, mixed with wet solids and drum dried to produce the final DDGS (Kim et al. 2008; Liu, 2011). The drying process applied at the last stage is intensive, as the air temperature can be over $500{ }^{\circ} \mathrm{C}$ at the dryer inlet and over $100{ }^{\circ} \mathrm{C}$ at the dryer outlet. Partial recycling of DDGS to the drum dryer can also occur in order to increase the drying efficiency of the equipment and improve the consistency of the produced 
53 DDGS (Kingsly et al. 2010). Overall, for $100 \mathrm{~kg}$ of grain approximately 40 litres of 54 ethanol, $32 \mathrm{~kg}$ of DDGS and $32 \mathrm{~kg}$ of $\mathrm{CO}_{2}$ are generated (Schingoethe, 2006).

Because it is enriched in protein, as well as in water-soluble vitamins and minerals, DDGS has been long marketed as feed for livestock (including poultry) (Klopfenstein, Erickson \& Bremer, 2008; Schingoethe, Kalscheur, Hippen \& Garcia, 2009). DDGS derived from wheat contains around $28-38 \%(\mathrm{w} / \mathrm{w})$ of protein, whereas for maize DDGS the protein levels range within 28-31\% (w/w) (Kim et al. 2010). The major parameters influencing the cost-effectiveness of bioethanol production from cereal grains include the cost of raw materials, as well as the revenue derived from DDGS. In Europe, bioethanol production is currently driven by the EU mandates on biofuel framework (Directive 2009/28/EC), thus the increased bioethanol demand is likely to result in increased DDGS availability. As a result, current research is focused on identifying alternative uses of DDGS, other than animal feed. To this end, existing bioethanol or distillery companies could implement a biorefinery approach, where DDGS is fractionated into several added value compounds including proteins, carbohydrates and phytochemicals.

In contrast to the literature on maize DDGS, a limited number of studies have investigated the extraction of protein from wheat-based DDGS (Bandara, Che \& Wu, 2011; Hong, Avramenko, Stone, Abbott, Classen \& Nickerson, 2012; Xu, Reddy \&Yang, 2007). Wheat grains contain gluten proteins that account for $80 \%$ of the total wheat protein, with the remaining $20 \%$ corresponding to a heterogeneous group of structural and metabolic proteins, including a major group of water soluble components with molecular weight (MW) lower than $25 \mathrm{kDa}$ (Veraverbeke \& Delcour, 2002). By contrast, gluten proteins are largely insoluble in water due to their 
high non-polar amino acids content (in particular proline and glutamine) and serve as storage reserves in the wheat grain (prolamins) (Shewry, 1999). Prolamins comprise both alcohol-soluble monomers (gliadins) and alcohol-insoluble polymers (glutenins) with the individual glutenin subunits being alcohol-soluble in their reduced state. Prolamin monomers and subunits show considerable diversity in MW, ranging from 10 to $100 \mathrm{kDa}$ (Shewry \& Halford, 2002). The extraction of proteins from DDGS at high yield and purity remains a challenge; DDGS proteins often show low extractability possibly due to the intensive heating applied at the final stage of the production process. Looking towards potential applications, DDGS proteins can be exploited for the production of biodegradable films, coatings and biodegradable plastics, which can be used for food, agricultural and industrial applications (Day, Augustin, Batey \& Wrigley, 2006). Wheat protein (gluten) has therefore been extensively studied as a natural starting material for the development of biodegradable films, due to its remarkable cohesive and elastic properties, as well as its susceptibility to chemical modifications (Irissin-Mangata, Bauduin, Boutevin \& Gontard, 2001; Kuktaine et al. 2011). Further applications of gluten include in aquaculture feed and in pet food, as an adhesive material in tapes and medical bandages, or as a biodegradable polymer material for the slow release of pesticides or fertilising agents (Day et al. 2006; Majeed, Ramli, Mansor \& Man, 2015).

The aim of this study was to investigate the extractability of proteins from various samples originating from a distillery plant, i.e. wheat DDGS, wet and spent solids (the latter also known as whole stillage). The composition of the extracted proteins and their amino acid content were determined and are discussed in order to evaluate the 
effect of the multi-step DDGS production process on the properties of the proteins at

101 each stage of production.

102

103

104

105

106

107

108

109

110

111

112

113

114

115

116

118

119

120

121

122

\section{Materials and methods}

\subsection{Raw materials}

Distillers' Dried Grains with Solubles (DDGS) and in-process samples of wet solids and spent solids were kindly provided by a distillery plant in UK. The distillery plant uses a mixture of $95 \%(\mathrm{w} / \mathrm{w})$ wheat and $5 \%(\mathrm{w} / \mathrm{w})$ barley as starting material for potable ethanol manufacture. After being received, samples were frozen at $-80{ }^{\circ} \mathrm{C}$. After determination of their moisture content (Section 2.2), samples were lyophilised in a VirTis Bench Top (USA) freeze-drier, initially set at $-55^{\circ} \mathrm{C}$ for $48 \mathrm{~h}$, packed in polyethylene bags and subsequently stored at $-20{ }^{\circ} \mathrm{C}$, until further analysis.

\subsection{Compositional analysis of samples}

All samples were milled using a conventional coffee grinder in order to reduce their particle size to less than $0.5 \mathrm{~mm}$. The moisture content was determined by drying at $105^{\circ} \mathrm{C}$ until a constant weight was reached (at least $18 \mathrm{~h}$ of drying needed). Ash was determined after drying the samples in a muffle furnace at $550 \pm 10{ }^{\circ} \mathrm{C}$ for at least $6 \mathrm{~h}$ until a constant weight was reached. Kjeldahl analysis was used to determine total protein using $\mathrm{N} \times 5.7$ as the conversion factor. Starch content was measured using the Megazyme total starch assay kit (Megazyme International, Ireland). The lipid content was measured gravimetrically after extraction with a Soxhlet apparatus using petroleum ether (Merck, Germany) as solvent.

The composition of the carbohydrates in the samples was determined after a two-step acid hydrolysis procedure according to the National Renewable Energy Laboratory 
123 protocol (NREL/TP-510-42618). The material (300 mg) was first hydrolysed with

$12472 \% \mathrm{v} / \mathrm{v}$ of sulphuric acid at $30{ }^{\circ} \mathrm{C}$ for $1 \mathrm{~h}$ and then in diluted acid $(4 \%, \mathrm{v} / \mathrm{v})$ at $121{ }^{\circ} \mathrm{C}$

125 for $30 \mathrm{~min}$. During hydrolysis the polysaccharides are hydrolysed into

126 monosaccharides (glucose derived from cellulose and $\beta$-glucan, and xylose and

127 arabinose derived from hemicellulose) which were quantified by HPLC (Agilent,

1281100 series $)$ with an Aminex HPX-87H column $(300 \mathrm{~mm} \times 7.8 \mathrm{~mm}$, Bio-Rad,

129 California, USA) and a refractive index detector. The operating conditions were:

130 sample volume $20 \mu \mathrm{L}$; mobile phase $0.005 \mathrm{M} \mathrm{H}_{2} \mathrm{SO}_{4}$; flow rate $0.6 \mathrm{~mL} / \mathrm{min}$; column

131 temperature $65{ }^{\circ} \mathrm{C}$. According to the NREL protocol, during acid hydrolysis lignin is

132 fractionated into acid soluble and acid insoluble material. Acid-soluble lignin was

133 measured with a UV-Vis spectrometer at $320 \mathrm{~nm}$ and acid-insoluble lignin

134 gravimetrically after subtracting the ash and protein contents of the samples. The

135 lignin content of samples is presented as the sum of acid soluble lignin and acid 136 insoluble residue.

137

138

139

140 141 (v/v) aqueous ethanol (Sigma, UK) and 50\% (v/v) 1-propanol (Merck, Germany) with

\subsection{Osborne fractionation of DDGS and in-process samples}

DDGS, wet and spent solid samples were subjected to Osborne fractionation according to the method of Lookhart and Bean (1995). Briefly, $100 \mathrm{mg}$ of sample were sequentially extracted with deionised water, $0.5 \mathrm{M} \mathrm{NaCl}$ (Sigma, UK), 70\% $1 \%(w / v)$ dithiothreitol (DTT) (Sigma, UK), in order to extract the water-soluble albumins, salt-soluble globulins, ethanol-soluble prolamins and ethanol-insoluble prolamins (as reduced subunits), respectively. A 1:10 (w/v) solids-to-liquid ratio was used for the extractions, which were performed in a thermomixer (Eppendorf, UK) with constant mixing $(1400 \mathrm{rpm})$, at $60{ }^{\circ} \mathrm{C}$ for $30 \mathrm{~min}$. Extractions for each sample 
were done in duplicate and the supernatants were collected by centrifugation $(8,000 \times g$

148 for $5 \mathrm{~min}$ ). In the case of sodium chloride, an additional wash with deionised water

149 was performed in order to remove the residual salt. The protein contents of the

150 Osborne fractionated supernatants were determined using the Bradford reagent assay

151 (Sigma, UK) (Bradford, 1976).

\section{2}

153

154

155

156

\subsection{Protein extraction}

\subsubsection{Aqueous-ethanol extraction of proteins}

Lyophilised and milled samples were subjected to protein extraction using different extraction conditions. Initially, all samples were treated with hexane at a 1:10 (w/v) solid-to-hexane ratio at room temperature for $8 \mathrm{~h}$ in order to remove the oil content. Hexane was removed by filtration though a Whatman No 1 paper and the solids were placed in an oven at $45{ }^{\circ} \mathrm{C}$ overnight to remove any residual hexane. A two-stage process was subsequently applied to the de-fatted samples to extract the water insoluble proteins. Specifically, $10 \mathrm{~g}$ of each sample were mixed with $70 \%$ (v/v) aqueous ethanol in a 1:10 (v/w) ratio and incubated under constant shaking for $30 \mathrm{~min}$ at different temperatures $\left(50,70\right.$ and $\left.90{ }^{\circ} \mathrm{C}\right)$. Supernatants were removed by centrifugation $(8,000 \times g, 15 \mathrm{~min})$ and the residues mixed with $70 \%(\mathrm{v} / \mathrm{v})$ of aqueous ethanol in a 1:10 (v/w) ratio containing varying concentrations of sodium metabisulfite (Fluka, UK) $(0.5,1.0$ or $1.5 \% \mathrm{w} / \mathrm{v})$ as reducing agent. After mixing the samples for $30 \mathrm{~min}$ at different temperatures, again at 50,70 and $90{ }^{\circ} \mathrm{C}$, they were centrifuged $\left(10,000 \times g\right.$, for $10 \mathrm{~min}$ at $\left.25^{\circ} \mathrm{C}\right)$, and the second step of the extraction was repeated. Deionised water was added to the collected supernatants in order to dilute the ethanol concentration to below $20 \%(\mathrm{v} / \mathrm{v})$ and the samples were placed at $-20{ }^{\circ} \mathrm{C}$ for $4 \mathrm{~h}$ to precipitate the proteins. The precipitated proteins were collected by 
171 centrifugation $\left(15,000 \times g\right.$, for $20 \mathrm{~min}$ at $\left.2{ }^{\circ} \mathrm{C}\right)$, washed with distilled water, lyophilized

172 in a VirTis Bench Top (USA) freeze-drier for $48 \mathrm{~h}$, and stored at $-20^{\circ} \mathrm{C}$.

\section{$173 \quad 2.4 .2$ Alkaline-ethanol extraction of proteins}

174 Alkaline conditions were also investigated for the extraction of the proteins in DDGS,

175 wet and spent solid samples. These were incorporated in the second stage of the 2-step

176 extraction process described in 2.4.1, in which aqueous ethanol (45 or 70\%, v/v) was

177 mixed with 0.05 or $0.1 \mathrm{M}$ of $\mathrm{NaOH}$ (Fluka, UK) and $1.0 \%$ (w/v) sodium

178 metabisulfite, in a solid-to-liquid ratio of 1:10. This extraction step was carried out

179 twice at $70{ }^{\circ} \mathrm{C}$ for $30 \mathrm{~min}$ and the supernatants were collected following

180 centrifugation $\left(10,000 \times g\right.$, for $10 \mathrm{~min}$ at $\left.25^{\circ} \mathrm{C}\right)$. Extracted proteins were then

181 precipitated with $2 \mathrm{M} \mathrm{HCl}$ at $\mathrm{pH} 5.5$ and collected by centrifugation $(15,000 \times g$, for 20

182 min at $10^{\circ} \mathrm{C}$ ), washed with distilled water, lyophilized (VirTis Bench Top, USA) and

183 stored at $-20{ }^{\circ} \mathrm{C}$. For both aqueous-ethanol and alkaline-ethanol extractions, the

184 protein contents of the dried extracted samples were determined by Kjeldahl analysis.

185 The protein content and protein yield of dried extracts were calculated as follows:

186 Protein content of extract $(\%)=\frac{\text { Total Kjeldalh Nitrogen } \times 5.7}{\text { Dry weight of extract }} \times 100$

Protein yield $(\%)=\frac{\text { Protein content of extract }}{\text { Protein concentration in original sample }} \times 100$

\subsection{SDS-PAGE of samples and protein isolates}

189 To identify the sub-units of water-insoluble proteins present in the original samples,

190 they were extracted sequentially according to Singh, Shepherd and Cornish (1991).

191 Briefly, gliadins were extracted three times from $20 \mathrm{mg}$ samples with $0.1 \mathrm{~mL} 50 \%$

192 (v/v) 1-propanol for $30 \mathrm{~min}$ at $65{ }^{\circ} \mathrm{C}$ and the supernatants from the three extractions

193 containing the gliadin fraction were collected by centrifugation $(3,000 \times g$ for 2 min) 
194 and pooled together. The solid residues, free of gliadins, were incubated with 50\%

195 (v/v) 1-propanol in $0.08 \mathrm{M}$ Tris- $\mathrm{HCl}(\mathrm{pH} 8.0)$ with $1 \%(\mathrm{v} / \mathrm{v})$ p-mercaptoethanol

196 (Sigma, UK) as reducing agent and 1.4\% (v/v) 4-vinylpyridine (Sigma, UK) as

197 alkylating agent of sulfhydryl groups, in order to extract glutenin subunits; the

198 supernatant containing the glutenin fraction was collected by centrifugation $(3,000 \times g$

199 for $2 \mathrm{~min}$ ). The supernatants containing the gliadin and glutenin fractions, 200 respectively, were diluted in sample buffer [2\% (v/v) SDS, 40\% (w/v) glycerol, $2010.02 \%(\mathrm{w} / \mathrm{v})$ bromoethyl-blue in $0.08 \mathrm{M}$ Tris- $\mathrm{HCl}(\mathrm{pH}=8.0)]$ and loaded onto a $1.0 \mathrm{~mm}$ 202 4-12\% Bis-Tris pre-casted gel (NuPAGE Novex, UK). Proteins were separated in an 203 XCell SurelockTM unit (Invitrogen, UK) at constant voltage (200 V) for $35 \mathrm{~min}$. Gels 204 were washed three times with purified water, stained with SimplyBlue SafeStain 205 buffer (Life Technologies, UK) for $1 \mathrm{~h}$ at room temperature and washed with distilled 206 water to obtain a clear background. The molecular weights of the visualised bands 207 were estimated using Novex Sharp pre-stained protein standards (Invitrogen, UK).

208 The protein fractions extracted after aqueous-ethanol and alkaline-ethanol treatments 209 of the samples were also separated based on their molecular weights using an XCell 210 SurelockTM unit (Invitrogen, UK) according to the protocol provided by the supplier.

211 Specifically, protein samples were reduced by treatment with NuPAGE LDS buffer 212 and reducing agent (dithiothreitol) at $70{ }^{\circ} \mathrm{C}$ for $10 \mathrm{~min}$. Electrophoresis was 213 performed as described above.

\section{$214 \quad 2.6$ Amino acid analysis}

215 The original solid samples as well as lyophilized protein extracts (10 $\mathrm{mg})$ were 216 hydrolysed using 6M HCl (Fluka, UK) and 1\% (w/v) phenol (Sigma, UK) at $110{ }^{\circ} \mathrm{C}$ 217 for $24 \mathrm{~h}$, in oxygen-free pressure tubes. After hydrolysis, aliquots $(100 \mu \mathrm{L})$ were 
218 neutralised and derivatised using the EZ-Faast amino acid derivatisation kit

219 (Phenomenex, UK). The kit is based on a solid-phase extraction that binds amino

220 acids and enables the derivatisation in aqueous solution of both the amine and

221 carboxylic groups of amino acids at room temperature. Amino acid profiles were 222 determined using a Gas Chromatography-Mass Spectrometry instrument (Agilent 223 6890/5975) as described by Elmore, Koutsidis, Dodson, Mottram \& Wedzicha (2005).

224 Norvaline was used as internal standard and detected amino acids were quantified 225 according to standard solutions supplied by the manufacturer. Methionine, cysteine 226 and tryptophan were not detected as they were degraded by acid hydrolysis.

\section{$227 \quad 2.7$ Thermogravimetric analysis (TGA)}

228 TGA analysis was carried out on the protein extracts using a Thermogravimetric 229 Analyzer (TA-Q600SDT TGA). $10 \mathrm{mg}$ samples were heated in an aluminium open 230 pan (Perkin-Elmer) from 30 to $800{ }^{\circ} \mathrm{C}$, with a heating rate of $20{ }^{\circ} \mathrm{C} / \mathrm{min}$ under 231 nitrogen flow $(20 \mathrm{~mL} / \mathrm{min})$.

\section{$232 \quad 2.8$ Statistical analysis}

233 Data are presented as mean values and their respective standard deviations from three 234 replicates. One-way ANOVA was used to calculate the significance between the 235 means of the samples treated under different extraction conditions at $\mathrm{p}<0.05$.

\section{Results and discussion}

\section{$238 \quad 3.1$ Composition of DDGS, wet solids and spent solids}

239 The compositions of DDGS, wet solids and spent solids are shown in Table 1 as 240 percentage concentration per dry weight basis $(\mathrm{db})$. As expected, the dry matter was 
241 higher in the case of DDGS, due to the thermal drying process carried out at the final 242 stage of DDGS production. By contrast, wet and spent solids contained significant 243 amounts of moisture (66.8\% and $77.9 \%$, respectively). In terms of protein, DDGS 244 contained around $30 \%(\mathrm{db})$ of protein, whereas lower concentrations were present in 245 wet $(20 \%, \mathrm{db})$ and spent solids $(25 \%, \mathrm{db})$. Similar values for wheat DDGS have been 246 previously reported (Pedersen et al. 2014; Cozannet et al. 2010; Ortín \& Yu, 2009), 247 with the small differences probably resulting from differences in the processes used 248 between different plants, seasonal variation in the harvested wheat, and a different N249 to-protein conversion factor (6.25 over 5.7). The lipid content was similar in DDGS $250(3.4 \% \mathrm{db})$ and wet solids $(2.9 \% \mathrm{db})$ but significantly higher $(\mathrm{P}<0.05)$ in spent solids $251(5.4 \%, \mathrm{db})$. Low concentrations of starch were detected in all samples (1.4-2.6\%, db). 252 In terms of the non-starch carbohydrate content, the values for cellulose and 253 hemicellulose (Table 1) did not vary significantly between DDGS and the in-process 254 samples. The ash content was slightly higher in spent solids $(4.4 \%, \mathrm{db})$ than in DDGS 255 (3.9\%, db). Thin stillage, and consequently spent solids, as also shown in this study, 256 typically contain the highest contents of ash among the different in-process samples 257 (Liu, 2011; Hong et al. 2012). Blending of wet solids with condensed thin stillage and 258 subsequent drying to give DDGS resulted in a lower ash content of DDGS compared 259 to spent solids. Finally, DDGS had a higher lignin content $(5.3 \%$, db) compared to 260 wet and spent solids. Pedersen et al. (2014) determined the composition of DDGS of 261 various origins, including wheat, maize and mixed cereals, and found differences in 262 the Klason lignin content among the DDGS samples. These were attributed to an 263 extent to the presence of non-lignin sources in the Klason lignin fraction, such as 264 Maillard-reaction products. The latter are formed during the mixing and drying of wet 
solids as a result of the reaction between reducing sugars and lysine residues, and are condensed in thin stillage (Pahm, Pedersen \& Stein, 2009).

\subsection{Osborne fractionation of DDGS and in-process samples}

269 A modified Osborne protocol was carried out for DDGS and in-process samples in order to identify the nature and solubility in different solvents of the various protein

271 fractions present in the samples (Fig 1). Salt-soluble globulins were the least abundant group in all samples, accounting for $14 \%(\mathrm{w} / \mathrm{w})$ of the total extracted protein in spent solids and about $10 \%(\mathrm{w} / \mathrm{w})$ or less in wet solids and DDGS, respectively. The albumin content varied significantly among samples; it was the major protein fraction of spent solids accounting for $\sim 41 \%(\mathrm{w} / \mathrm{w})$, followed by $\sim 18 \%(\mathrm{w} / \mathrm{w})$ in DDGS and $\sim 10 \%(\mathrm{w} / \mathrm{w})$ in wet solids. Taking into account the fact that spent solids are a mixture of fermentation liquid and grain residues, it is expected that a substantial amount of the protein content in spent solids could be attributed to non-gluten proteins. These are mainly water soluble, metabolic or structural proteins and also include the 280 amylolytic enzymes used in the fermentation process. Moreover, from a process point 281 of view, the mixing of wet solids and the concentration of thin stillage taking place 282 during the production of DDGS, contributed considerably to the presence of about $28320 \%$ of albumins in DDGS. Alcohol soluble gliadins were the second most abundant 284 protein fraction in all samples. Small differences in their concentration occurred 285 between spent and wet solids (Fig. 1), whereas in DDGS they accounted for 33\% $286(\mathrm{w} / \mathrm{w})$ of the total extracted protein. Despite the fact that gliadins are readily soluble in 287 aqueous alcohol, it is unlikely that they are solubilised during the fermentation 288 process, as the ethanol concentration is only around $18 \%(\mathrm{v} / \mathrm{v})$ at the end point of the 289 fermentation. Glutenins were the major fraction in wet solids and DDGS, accounting 
for $55 \%(\mathrm{w} / \mathrm{w})$ and $42 \%(\mathrm{w} / \mathrm{w})$ of the total extracted protein, respectively. Glutenins and gliadins contain high levels of proline and glutamine and serve as storage proteins in the starchy endosperm cells of the wheat grain (Shewry et al., 2002). Glutenins comprise a heterogeneous mixture of high and low molecular weight subunits assembled into polymers stabilised by inter-chain disulphide bonds (Veraverbeke \& 295 Delcour, 2002). However, they are only extractable in aqueous alcohol as reduced subunits in the presence of a reducing agent. It should be noted that the yield of total extracted proteins according to the Osborne fractionation method (measured by 298 Bradford and compared to the initial protein content of the samples), was $20.3 \%$ for 299 DDGS, $27.9 \%$ for wet solids and $28.4 \%$ for spent solids, respectively. Although the 300 Osborne method has been widely used to extract proteins based on solubility, 301 quantification can be problematic due to the fact that the different protein groups can 302 overlap in their solubility in the different solvents, leading to partial cross303 contamination of the fractions (Shewry, 1999; DuPont, Chan, Lopez \& Vensel, 2005). 304 However, in our study, Osborne fractionation proved to be a useful tool for 305 identifying key differences between the protein contents of the samples, and 306 demonstrated the influence of certain process steps on specific protein groups, such as 307 albumins.

308 In order to further characterise the protein content of DDGS and in-process samples, 309 prolamins were sequentially extracted according to the protocol of Singh, Shepherd 310 and Cornish (1991). SDS PAGE analysis (Fig 2a) of the gliadins and glutenins present 311 in spent solids, wet solids and DDGS was conducted. Based on the molecular weight 312 ladder (lane 1), distinctive bands with molecular weight of around $50 \mathrm{kDa}$ were 313 present in spent and wet solids, corresponding to $\omega$-gliadins, as well as bands with 314 molecular weights of 40 and $30 \mathrm{kDa}$, corresponding $\alpha$ - and $\gamma$-gliadins, respectively. In 
315 DDGS, only bands corresponding to $\omega$-gliadins were distinctively present. It has been 316 reported that high temperatures (above $100^{\circ} \mathrm{C}$ ) can result in re-arrangements leading

317 to the formation of new disulphide bonds among the sulphur-rich $\alpha, \beta$ - and $\gamma$-gliadins, 318 whereas $\omega$-gliadins do not contain cysteine residues and thus cannot form disulphide 319 bonds (Schofield et al. 1983). This could explain the presence of only $\omega$-gliadins in 320 the DDGS sample, as the latter is subjected to an intensive thermal treatment at the 321 last stage of its production (drum drying). All samples demonstrated intense bands at 322 the top of the gel, suggesting the presence of high molecular weight aggregates of 323 glutenin or gliadin subunits or even polymerised gliadins that were not able to enter 324 the gel. Distinctive bands corresponding to low molecular weight glutenin subunits 325 were present in spent and wet solids $(30-60 \mathrm{kDa})$, whereas these bands were only 326 present in traces in DDGS. The intensities of the glutenin bands on the SDS-PAGE 327 gels confirmed the results obtained from the Osborne fractionation which indicated 328 that glutenins were the most abundant proteins in the samples. In most of the gliadin 329 and glutenin protein fractions, a clear band was obtained around $20 \mathrm{kDa}$. This could 330 correspond to albumins, resulting from partial cross-contamination during Osborne 331 fractionation, or partially hydrolysed proteins.

\subsection{Extraction of proteins from DDGS and in-process samples}

334 One of the major goals of this study was to investigate the methodology for the 335 extraction of proteins from DDGS and in-process samples. Water-insoluble proteins 336 (i.e. gliadins and glutenins) were mainly targeted, as these could serve as suitable 337 starting materials for the development of biodegradable polymers for food and non338 food applications, as previously shown for gliadins and glutenins derived from wheat 339 grains (Kuktaite et al. 2011; Lagrain et al. 2010). Gliadins and reduced glutenin 
340 subunits are both soluble in aqueous (60-70\% v/v) ethanol (Shewry, 1999). Reducing

341 agents are typically used to improve protein extraction, as they reduce the disulphide 342 bonds present both within (intra-chain) and between (inter-chain) gluten protein 343 subunits (Shewry \& Tatham, 1997). Dithiothreitol (DDT) and $\beta$-mercaptoethanol ( $\beta$ 344 ME) are most widely utilised for this purpose. However, these chemicals are not 345 suitable for commercial production because of their toxicity. Alternatively, sodium 346 metabisulfite is a preferable reducing agent, as it is food grade and has lower toxicity 347 and odour compared to other reducing agents (Park, Bean, Wilson \& Schober, 2006).

348 The first set of extraction experiments was carried out using $70 \%(\mathrm{v} / \mathrm{v})$ aqueous 349 ethanol, in order to determine the effects of temperature and reducing agent 350 concentration on protein extractability. The protein content of the dried extracts as 351 determined by Kjeldalh analysis is presented in Table 2. Extraction at $50{ }^{\circ} \mathrm{C}$ resulted 352 in low protein content, ranging between 14-32\%, in all extracts depending on the 353 reducing agent concentration. The greatest amount of protein was present in the 354 extracts from the wet solids $(\sim 32 \%)$ followed by spent solids $(\sim 23 \%)$ and then DDGS $355(\sim 14 \%)$. Extraction at $70{ }^{\circ} \mathrm{C}$ improved significantly $(\mathrm{P}<0.05)$ the protein content of all 356 samples compared to $50{ }^{\circ} \mathrm{C}$, with the highest being $\sim 45 \%$ for DDGS, $\sim 58 \%$ for wet 357 solids and $\sim 62 \%$ for spent solids; the optimum reducing agent concentration was in 358 most cases $1 \%$. At $90{ }^{\circ} \mathrm{C}$ the protein content of the extracts decreased significantly $359(\mathrm{P}<0.05)$ compared to that at $70{ }^{\circ} \mathrm{C}$ for all samples. In terms of the protein extraction 360 yield ( $\%$ of protein per total protein of original sample), the best extraction conditions 361 were identified as $70{ }^{\circ} \mathrm{C}$ and $1 \%$ reducing agent, resulting in protein extraction yields 362 of $30.1 \%(\mathrm{w} / \mathrm{w})$ for DDGS, $55.3 \%(\mathrm{w} / \mathrm{w})$ for wet solids and $52.1 \%(\mathrm{w} / \mathrm{w})$ for spent 363 solids. 
364 In the presence of ethanol, only the hydrophobic fraction of wheat protein is 365 solubilised, as a result of the disruption of low-energy hydrogen bonds in the 366 decreased dielectric constant of the medium. Reduction of the disulphide bonds is 367 responsible for the solubilisation of small amounts of $\omega$-gliadins that are present in 368 glutenin (the D type low molecular weight subunits) and some low molecular weight 369 glutenin subunits, which in turn renders the remaining gluten proteins (comprising 370 high molecular weight glutenins as well as $\alpha$-, $\beta$ - and $\gamma$-gliadins) soluble in hot ethanol 371 solution (Mimouni, Robin, Azanza \& Raymond, 1998). In this study, the use of 372 reducing agent and $70{ }^{\circ} \mathrm{C}$ led to the extraction of water-insoluble prolamins, with the 373 extraction efficiency being dependent on the starting material. However, at elevated 374 temperatures (around $100{ }^{\circ} \mathrm{C}$ ), the rich-sulphur $a-, \beta$ - and $\gamma$-gliadins undergo 375 disulphide bond rearrangements which reduces their solubility; this could be the 376 reason for the lower protein extraction seen in the case of DDGS compared to the 377 other samples in all extraction temperatures, and particularly at $90{ }^{\circ} \mathrm{C}$ (Table 2). 378 Moreover, under such conditions, glutenin polymerisation can occur via sulphydryl379 disulphide inter-chain exchange reactions between polymers (Lagrain et al., 2008). 380 The latter may be further facilitated by a temperature-dependent unfolding of the 381 tertiary structure of the proteins. Recently, Hong and co-workers (2012) stated that the 382 protein extraction efficiency of samples post-distillation (i.e. spent solids) is higher 383 compared to DDGS, as a result of heat-induced protein denaturation and increased 384 disulphide bonding within and among proteins, which occurs during the final drum 385 drying step of the process.

386 The second set of extraction experiments was carried out using an alkaline-aqueous 387 ethanol solution at $70{ }^{\circ} \mathrm{C}$ and a reducing agent concentration of $1.0 \%$, as these were 
388 shown from the previous experiments to be the optimal conditions for extraction. 389 Alkalis and acids can partially hydrolyse protein molecules into smaller peptide 390 fragments, which typically increases their solubility and extractability. In these 391 experiments, the proteins were extracted with $45 \%$ or $70 \%$ (v/v) aqueous ethanol in 392 the presence of $0.05 \mathrm{M}$ or $0.1 \mathrm{M}$ of $\mathrm{NaOH}$. As shown in Table 2, $45 \%$ ethanol 393 combined with $0.05 \mathrm{M} \mathrm{NaOH}$ resulted in low protein contents in the extracts derived 394 from wet and spent solids ( 13\% and 20\%, respectively) and DDGS ( 21\%). The 395 extractability of proteins was significantly $(\mathrm{P}<0.05)$ increased with $70 \%(\mathrm{v} / \mathrm{v})$ ethanol, 396 in particular in the presence of relatively high concentrations of alkali $(0.1 \mathrm{M})$; the 397 protein content of the dried extracts was $\sim 39 \%$ for DDGS, $\sim 49 \%$ for wet solids and $398 \sim 52 \%$ for spent solids, whereas the extraction yields were $27.1 \%$ for DDGS, $33.4 \%$ 399 for wet solids and $31.2 \%$ for spent solids, respectively.

400 SDS-PAGE analyses of the proteins in the aqueous ethanol and alkaline-aqueous 401 ethanol extracts are shown in Fig 2b. For both extraction methods, distinctive bands 402 were obtained for all samples in the range of 35-50 kDa, most likely corresponding to 403 a mixture of $\alpha-\gamma$ - and $\omega$-gliadins and low molecular weight glutenin subunits. 404 Visualisation of the gels suggests that the profile of the extracted proteins was not 405 considerably affected by the extraction conditions, and that the main differences in the 406 protein content of the extracts obtained under the different conditions were primarily 407 quantitative rather than qualitative.

408 Taking the above results into account, it can be deduced that aqueous ethanol 409 extraction ( $\mathrm{pH}$ 10) was a more efficient method for the extraction of proteins from 410 the wheat DDGS and in-process samples compared to alkaline-aqueous ethanol 411 extraction ( $\mathrm{pH}$ 12). Utilising aqueous ethanol for extraction of proteins from DDGS 
or in-process samples would be particularly attractive for distilleries and bioethanol

413 plants. Moreover, the presence of alkali in the extraction process could result in 414 corrosion of equipment in the long-term.

415 Although the literature on the extraction of proteins from wheat DDGS is limited, a 416 few studies have studied the extraction of proteins from DDGS from other cereals. $\mathrm{Xu}$ 417 et al. (2007) reported an extraction yield of $44 \%$ with $90 \%$ protein content for corn 418 DDGS using $70 \%$ ethanol and $0.25 \%$ sodium sulfite at acidic $\mathrm{pH}$. More recently, in a 419 two fraction extraction process with $70 \%(\mathrm{v} / \mathrm{v})$ aqueous 2-propanol and $70 \%(\mathrm{v} / \mathrm{v})$ 420 aqueous ethanol, Anderson, Ilankovan \& Lamsai (2012) achieved an extraction yield 421 of $70 \%$ of $\alpha$-zein from maize DDGS. In another study, Wang, Tilley, Bean, Sun \& 422 Wang (2009) investigated the extraction efficiency of kafirin proteins (prolamins) 423 from sorghum DDGS and reported an extraction yield of $44 \%$ with a kafirin content 424 of $98.8 \%$ using acetic acid under reducing conditions. In the same context, Bandara et 425 al. (2011) studied the efficiency of protein extraction from triticale DDGS and 426 demonstrated that alkaline-ethanol conditions gave extraction yields between $21-30 \%$ $427(\mathrm{w} / \mathrm{w})$ and a maximum protein content of $\sim 66 \%(\mathrm{w} / \mathrm{w})$. The present study is the first to 428 investigate the extraction of proteins from in-process samples produced during the 429 wheat DDGS production. Comparison of the extractability of proteins within samples 430 shows that wet solids are the most appropriate starting material for protein extraction. 431 Under optimal extraction conditions, $55.3 \%$ of the total protein was recovered from 432 wet solids, with a protein content of $58 \%$ (w/w). From an industrial perspective, 433 protein recovery and purity are very important for the translation of the process to 434 large scale extraction. Commercial gluten products extracted from wheat contain 435 around $75 \%$ protein. Therefore, efficient extraction using DDGS or in-process 
samples as starting material should ideally result in a protein-rich extract with a

437 similar purity. To this end, the addition of an ultrafiltration step post-reduction would

438 reduce the amounts of carbohydrates and other non-protein components in the protein

439 extracts and increase their purity.

\subsection{Composition of protein extracts and solid residues}

441 Table 3 shows the compositions of the protein extracts and their respective solid

442 residues after ethanol extraction of DDGS, spent and wet solids samples. Very small

443 amounts of water-soluble carbohydrates were detected in all aqueous ethanol extracts

$444 \quad(2.4-5.1 \%, w / w)$, with the spent solids containing the smallest amount. Glucose was

445 the major monosaccharide determined after hydrolysis, indicating the presence of

446 starch followed by xylose and arabinose, the latter indicating the presence of soluble

447 arabinoxylans, which are the major non-starch polysaccharides in wheat grain

448 (Saulnier, Peneau \& Thibault, 1995). On the other hand, the solid residue after

449 extraction had a high content of water unextractable polysaccharides which was

450 around $49 \%(\mathrm{w} / \mathrm{w})$ for all samples. The monosaccharides composition (Table 3)

451 indicated the presence of insoluble $\beta$-glucan, cellulose and water unextractable

452 arabinoxylan. The protein content of the solid residues was $\sim 4.7 \%$ for spent solids,

$453 \sim 7.4 \%$ for wet solids and $\sim 11.6 \%$ for DDGS, i.e. the reverse ranking of that obtained

454 for protein extractability.

455 Moreover, the mass balances for the principal components (i.e. protein and 456 carbohydrates) were calculated. It should be noted that because the current study 457 focused on the extraction of water-insoluble proteins, the contents of gliadins and 458 glutenins determined by Osborne analysis (Fig 1) were taken into account for 459 calculating the protein mass balance. Based on the data in Table 1 , only $\sim 69 \%$ of the 
initial protein (gliadins and glutenins) content was recovered from DDGS. This could

461 be attributed to only partial precipitation of the low molecular weight proteins in the extraction liquid, as well as to the thermal denaturation of DDGS proteins during the drying stage. At the drying stage DDGS is subjected to intense and prolonged thermal

464 treatment (higher than $100^{\circ} \mathrm{C}$ ). Under these conditions, the disulphide bonds present 465 in all wheat gluten proteins (except $\omega$-gliadins) may undergo rearrangements to form 466 cross-links in highly insoluble denatured aggregates (Wang, Wei, Li, Bian \& Zhao, 467 2009; Hong et al. 2012). On the other hand, protein recoveries from wet and spent 468 solids were noticeably higher (89-93\%), reflecting the higher protein extractability of 469 these samples. In terms of the carbohydrate mass balances, the recoveries ranged from 47086 to $94 \%$ for all samples. These values are very good considering that approximately $4715 \%$ of the material could be lost during the intermediate washing steps. The high 472 carbohydrate contents of the solid residues after protein extraction indicate that these 473 materials could be a potential source of non-starch polysaccharides, and if processed 474 to oligosaccharides could provide functional ingredients (prebiotics, stabilisers, 475 emulsifiers) for food and non-food applications.

476 Further information on the proteins present in the extracts of DDGS and wet solids 477 was provided by thermogravimetric analysis (TGA). Degradation of the samples was 478 carried out under nitrogen and the observed peaks are presented as derivatives of the 479 weight loss as a function of temperature. As depicted in Fig 4, a peak was identified 480 for both samples at around $53-60^{\circ} \mathrm{C}$. This was more intense in the case of wet solids 481 and corresponded to the loss of free and bound water. Extracts of both DDGS and wet 482 solids exhibited a prominent broad peak in the range of $230-370^{\circ} \mathrm{C}$, which was 483 attributed to the breakage of the covalent peptide bonds of amino acids, as well as to 
the cleavage of disulphide, O-N and O-O bonds in protein molecules (Sun, Song \& Zheng, 2007). Moreover, the analysis showed an additional peak for the DDGS extract at about $730^{\circ} \mathrm{C}$, which is probably associated with the degradation of lignin components (Sahoo, Seydibeyoğlu, Mohanty \& Misra, 2011).

\subsection{Amino acid compositions of solid samples and protein extracts}

490 Fig 5a shows the relative concentrations of amino acids in hydrolysates of the DDGS,

491 wet and spent solids samples. Glutamic acid (which is mostly derived from the 492 deamidation of glutamate), proline, leucine and phenylalanine were the major amino 493 acids in the samples and are representative of wheat gluten proteins (Wieser, 2007). It 494 is worth noting the reduced concentration of lysine in the DDGS sample, as lysine is 495 the limiting essential amino acid in wheat grain proteins for the nutrition of humans 496 and monogastric livestock (Shewry, 2007) but is labile to heating (Almeida, Htoo, 497 Thomson \& Stein, 2013). Fig 5b shows the relative concentration of individual amino 498 acids in the wet solid and DDGS protein samples, obtained after aqueous ethanol and 499 alkaline-aqueous ethanol extraction. The increased amino acid content of the wet solid extracts reflects the increased protein extractability of wet solids compared to the 501 intensively thermally treated DDGS sample. Comparing the amino acid profile 502 obtained between the two extraction methods, aqueous ethanol conditions showed 503 increased specificity towards glutamic acid, phenylalanine and proline. These amino 504 acids are present in $\alpha-, \gamma-, \omega$-gliadins and low molecular subunits of glutenin (Shewry, 505 Tatham, Forde, Kreis \& Miflin, 1986) and as shown by SDS-PAGE, these were the 506 major protein groups in the extracts. Apart from the potential utilisation of protein 507 extracts as starting material for biodegradable plastics, the high content of glutamic 508 acid could justify its extraction and utilisation as building block for chemical 
509 compounds such as succinonitrile or acrylonitrile (Lammens, Franseen, Scott \& 510 Sanders, 2012). To this end, glutamic acid is a non-essential amino acid and its 511 extraction would not compromise the nutritional value of DDGS used as livestock 512 feed.

\section{4. Conclusions}

514 Aqueous ethanol extraction was more effective than alkaline-aqueous ethanol for 515 extracting water-insoluble proteins from DDGS and in-process samples. The 516 extractability of the proteins and their compositional characteristics were highly 517 influenced by the starting raw material, i.e. wet solids, spent solids or DDGS. Protein 518 was less efficiently extracted from DDGS, probably due to the decreased solubility of 519 protein aggregates formed during the intensive thermal treatment during the drum 520 drying stage. This is also indicated by the low recovery of $\alpha$ - and $\gamma$-gliadins. The wet 521 solids exhibited the highest protein extractability (gliadins and glutenins), with a 522 maximum recovery yield of $55 \%(\mathrm{w} / \mathrm{w})$ (on the basis of total protein) and a protein 523 content of $58 \%(\mathrm{w} / \mathrm{w})$, and hydrolysates were particularly rich in glutamic acid and 524 proline. The solid residues after extraction had a high carbohydrate content, which 525 renders them amenable to enzymatic processing for the production of bioactive 526 carbohydrates, such as prebiotic oligosaccharides, or for use as fibre-rich livestock 527 feed. Overall, the research demonstrated the feasibility of utilising in-process samples 528 from the DDGS production process for the extraction of proteins with good 529 commercial potential.

\section{Acknowledgements}


532 The authors would like to acknowledge the Integrated Biorefining Research and

533 Technology Club (IBTI) of the UK Biotechnology and Biological Sciences Research

534 Council (BBSRC) for their financial support on a collaborative research project

535 entitled "Development of a process scheme for the production of high value 536 functional products from DDGS” (BB/J019429/1-University of Reading; 537 BB/J019380/1 - Rothamsted Research).

\section{$538 \quad$ References}

539 Almeida, F.N., Htoo, J.K., Thomson, J., Stein, H.H. (2013). Amino acid digestibility 540 of heat damaged distillers dried grains with soluble fed to pigs. Journal of Animal $541 \quad$ Science and Biotechnology, 4, 44-54.

542 Anderson, T.J., Ilankovan, P., Lamsai, B.P. (2012). Two fraction extraction of $\alpha$-zein 543 from DDGS and its characterization. Industrial Crops and Products, 37, 466-472.

544 Bandara N, Chen L, Wu J. (2011). Protein extraction from triticale distillers grains. $545 \quad$ Cereal Chemistry, 88, 553-559.

546 Bradford, MM. (1976) A rapid and sensitive method for the quantitation of 547 microgram quantities of protein utilizing the principle of protein-dye binding. $548 \quad$ Analytical Biochemistry, 72, 248-254.

549 Cozannet, P., Primot, Y., Gady, C., Métayer, J.P., Callu, P., Lessire, M., Skiba, F., 550 Noblet, J. (2010). Ileal digestibility of amino acids in wheat distillers dried grains $551 \quad$ with solubles for pigs. Animal Feed Science and Technology, 158, 177-186.

552 Day, L., Augustin, M.A., Batey, I.L., Wrigley, C.W. (2006). Wheat-gluten uses and 553 industry needs. Trends in Food Science and Technology, 17, 82-90.

554 Directive 2009/28/EC of the European Parliament and of the Council on the 555 promotion of the use of energy from renewable sources and amending and 

L140/16.

DuPont, F.M., Chan, R., Lopez, R., Vensel, W.H. (2005). Sequential extraction and quantitative recovery o gliadins, glutenins and other proteins from small samples

\section{1}

562 of wheat flour. Journal of Agriculture and Food Chemistry, 53, 1575-1584.

Elmore, J.S., Koutsidis, G., Dodson, A.T., Mottram, D., Wedzicha, B. (2005). Measurement of acrylamide and its precursors in potato, wheat and rye model systems. Journal of Agricultural and Food Chemistry, 53, 1286-1293.

Hong, G.P., Avramenko, N., Stone, A., Abbott, D., Classen, H., Nickerson M. (2012). Extractability and molecular modification of gliadin and glutenin proteins withdrawn from different stages of a commercial ethanol fuel/distillers dried grains with solubles process using a wheat feedstock. Cereal Chemistry, 89, 276283.

Irissin-Mangata, J., Bauduin, G., Boutevin, B., Gontard, N. (2001). New plasticizer for wheat gluten films. European Polymer Journal, 37, 1533-1541.

Kim, Y., Mosier, N.S., Hendrickson, R., Ezeji, T., Blaschek, H., Dien, B., Cotta, M., Dale, B., Ladisch, M.R. (2008). Composition of corn dry-grind ethanol byproducts: DDGS, wet cake and thin stillage. Bioresource Technology, 99, 51655176.

Kim, Y., Hendrickson, R., Mosier, N.S., Ladisch, M.R., Bals, B., Balan, V., Dale, B.E., Dien, B.S., Cotta, M.A. (2010). Effect of compositional variability of distillers' grains on cellulosic ethanol production. Bioresource Technology, 101, 5385-5393.

Kingsly, A.R.P., Ileleji, K.E., Clementson, C.L., Garcia, A., Maier, D.E., Stroshine, R.L., Radcliff, S. (2010). The effect of process variables during drying on the 
physical and chemical characteristics of corn dried distillers grains with soluble (DDGS)-Plant scale experiments. Bioresource Technology, 101, 193-199.

583 Klopfenstein, T.J., Erickson, G.E., Bremer, V.R. (2008). Use of distillers by-products in the beef cattle feeding industry. Journal of Animal Science, 86, 1223-1231.

Kuktaine, R., Privelic T.S, Cerenius, Y., Hedenqvist, M.S, Gällstedt, M.,Marttila, S., Ignell, R., Popineau, Y., Tranquet, O., Shewry, P.R., Johansson, E. (2011). Structure and morphology of wheat gluten films: From polymeric protein aggregates toward superstructure arrangements. Biomacromolecules, 12, 14381448. 541.

Lammens, T.M., Franssen, M.C.R., Scott, E.L., Sanders, J.P.M. (2012). Availability of protein-derived amino acids as feedstock for the production of bio-based chemicals. Biomass and Bioenergy, 44, 168-181.

Liu, K. (2011). Chemical composition of distillers grains, a review. Journal of Agricultural and Food Chemistry, 59, 1508-1526.

Lookhart, G.L., Bean, S.R. (1995). Separation and characterization of wheat protein fractions by high-performance capillary electrophoresis. Cereal Chemistry, 72(6),

601 Majeed, Z., Ramli, N.K, Mansor, N., Man, Z. (2015) A comprehensive review on 602 biodegradable polymers and their blends used in controlled-release fertilizer 603 processes. Reviews in Chemical Engineering, 31, 69-95. 
604 Mimouni, B., Robin, J.M., Azanza, J.L., Raymond, J. (1998). Wheat flour proteins: 605 Isolation and functionality of gliadin and HMW-glutenin enriched fractions. $606 \quad$ Journal of the Science of Food and Agriculture, 78, 423-428.

607 Ortín, W.G.N., Yu, P. (2009). Nutrient variation and availability of wheat DDGS, 608 corn DDGS and blend DDGS from bioethanol plants. Journal of the Science of $609 \quad$ Food and Agriculture, 89, 1754-1761.

610 Pahm, A.A., Pedersen, C., Stein, H.H. (2009). Standardized ileal digestibility of 611 reactive lysine in distillers dried grains with soluble fed to growing pigs. Cereal $612 \quad$ Chemistry, 57, 535-539.

613 Park, S.H., Bean, S.R., Wilson, J.D., Schober, T.J. (2006). Rapid isolation of sorghum 614 and other cereal starches using sonication. Cereal Chemistry, 83, 611-616.

615 Pedersen, M.B., Dalsgaard, S., Knudsen, K.E.B., Yu, S., Lærke, H.N. (2014). 616 Compositional profile and variation of distillers dried grains with soluble from 617 various origins with focus on non-starch polysaccharides. Animal Feed Science 618 and Technology, 197, 130-141.

619 Sahoo, S., Seydibeyoğlu, M.Ö., Mohanty, A.K., Misra, A. (2011). Characterization of 620 industrial lignins for their utilisation in future value added applications. Biomass

622 Saulnier, L., Peneau, N., Thibault, J.F. (1995). Variability in grain extract viscosity and water-soluble arabinoxylan content in wheat. Journal of Cereal Science, 22,

625 Schingoethe, D.J., Kalscheur, K.F., Hippen, A.R., Garcia, A.D. (2009). Invited 626 review: The use of distillers products in dairy cattle diets. Journal of Dairy 627 Science, 92, 5802-5813. 
628 Schingoethe, D.J. (2006). Utilization of DDGS by cattle. Proc. $27^{\text {th }}$ Western Nutrition Conf, Winnipeg, Manitoba, Canada, 19-20.

630 Schofield, J. D., Bottomley, R. C., Timms, M. F., and Booth, M. R. (1983). The effect 631 of heat on wheat gluten and the involvement of sulphydryldisulphide interchange 632 reactions. Journal of Cereal Science, 1, 241-253.

633 Shewry, P.R. (2007). Improving the protein content and composition of cereal grain. Journal of Cereal Science, 46, 239-250.

635 Shewry, P.R., Halford, N.G. (2002). Cereal seed storage proteins: structures, 636 properties and role in grain utilisation. Journal of Experimental Botany, 53, 947637958.

638 Shewry, P.R. (1999). The synthesis, processing and deposition of gluten proteins in 639 the developing wheat grain. Cereal Food World, 44, 587-589.

640 Shewry, P.R., Tatham, A.S. (1997). Disulphide bonds in wheat gluten proteins. $641 \quad$ Journal of Cereal Science, 25, 207-227.

642 Shewry, P.R., Tatham, A.R., Forde, J., Kreis, M., Miflin, B.J. (1986). The 643 classification and nomenclature of wheat gluten proteins: A reassessment. $644 \quad$ Journal of Cereal Science, 4, 97-106.

645 Singh, N.K., Shepherd, K.W., Cornish, G.B. (1991). A simplified SDS-PAGE 646 procedure for separating LMW subunits of glutenin. Journal of Cereal Science, $647 \quad 14,203-208$.

648 Sun, S., Song, Y., Zheng, Q. (2007). Morphologies and properties of thermo-molded 649 biodegradable plastics based on glycerol-plasticized wheat gluten. Food $650 \quad$ Hydrocolloids, 21, 1005-1013. 
651 Veraverbeke, W.S., Delcour, J.A. (2002). Wheat protein composition and properties 652 of wheat glutenin in relation to breadmaking functionality. Critical Reviews in 653 Food Science and Nutrition, 42, 179-208.

654 Wang, Y., Tilley, M., Bean, S., Sun, X.S., Wang, D. (2009). Comparison of methods 655 for extraction of kafirin proteins from sorghum distillers dried grains with 656 solubles. Journal of Agricultural and Food Chemistry, 57, 8366-8372.

657 Wang, J., Wei, Z., Li, L., Bian, K., Zhao M. (2009). Characteristics of enzymatic 658 hydrolysis of thermal-treated wheat gluten. Journal of Cereal Science, 50, 205659209.

660 Wieser, H. (2007). Chemistry of gluten proteins. Food Microbiology, 24, 115-119.

661 Xu, W., Reddy, N., Yang, Y. (2007). An acidic method of zein extraction from 662 DDGS. Journal of Agricultural and Food Chemistry, 55, 6279-6284.

663 
Table 1. Chemical composition of DDGS and in-process samples

\begin{tabular}{lccc}
\hline \multicolumn{1}{c}{$($ in \%, db) } & DDGS & Wet solids & Spent solids \\
\hline Dry matter & $96.6 \pm 0.7$ & $33.2 \pm 1.1$ & $22.1 \pm 1.2$ \\
Crude protein & $29.1 \pm 1.7$ & $19.8 \pm 1.2$ & $25.6 \pm 1.1$ \\
Crude fat & $3.4 \pm 0.1$ & $2.9 \pm 0.9$ & $5.4 \pm 0.4$ \\
Cellulose and $\boldsymbol{\beta}$-glucan & $14.9 \pm 0.4$ & $15.1 \pm 0.6$ & $16.3 \pm 1.1$ \\
Starch & $2.6 \pm 0.10$ & $2.0 \pm 0.3$ & $1.4 \pm 0.19$ \\
Hemicellulose & $25.1 \pm 1.6$ & $28.0 \pm 1.3$ & $25.5 \pm 0.9$ \\
& $(16.7 \pm 0.9)$ & $(18.4 \pm 0.7)$ & $(16.7 \pm 0.6)$ \\
& $(8.3 \pm 0.8)$ & $(9.6 \pm 0.6)$ & $(8.9 \pm 0.3)$ \\
Lignin & $5.3 \pm 0.7$ & $4.1 \pm 0.5$ & $3.8 \pm 0.3$ \\
Ash & $3.9 \pm 0.5$ & $2.1 \pm 0.3$ & $4.4 \pm 0.6$ \\
\hline
\end{tabular}

665

666

667 


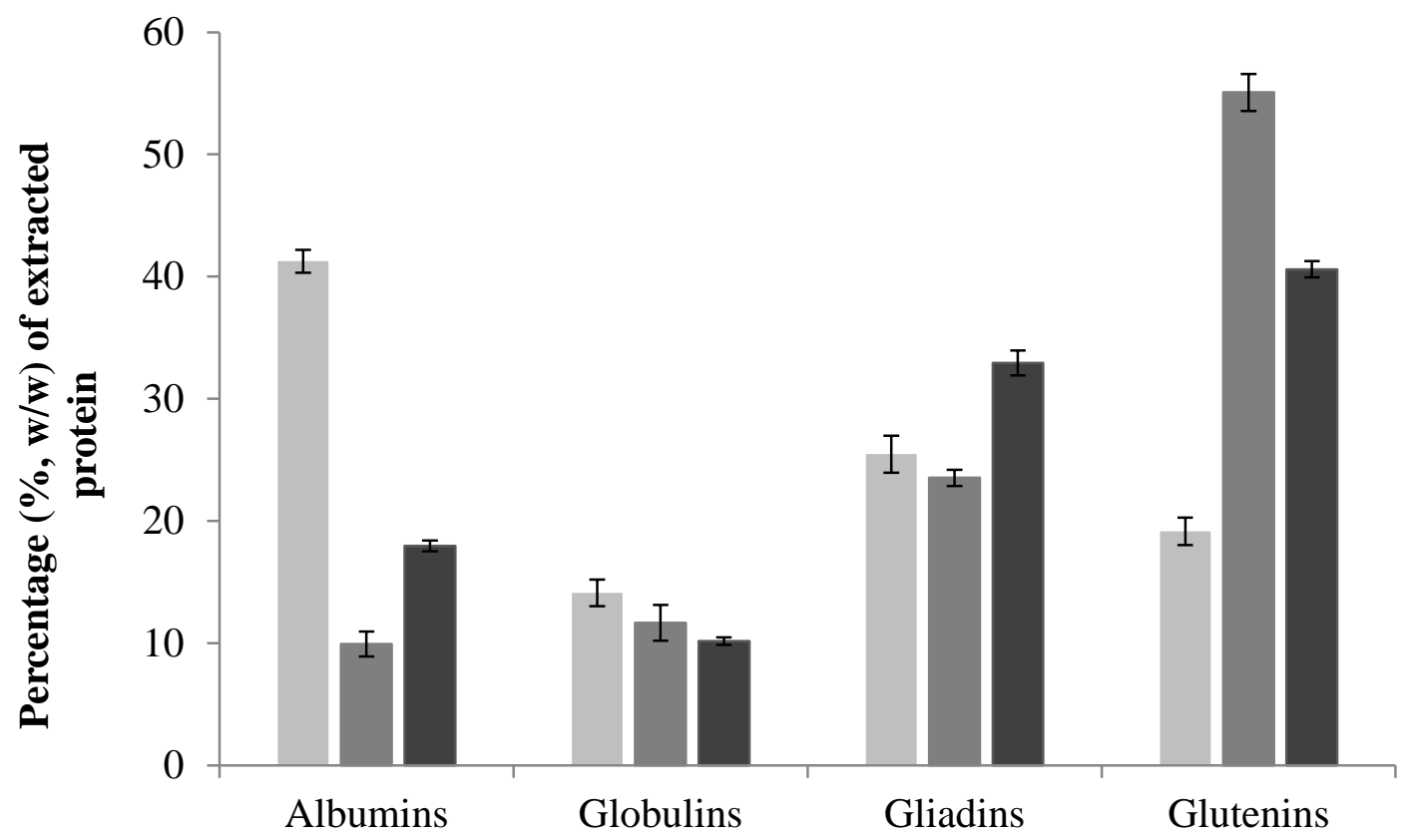

670 Fig. 1 Protein composition of fractionated spent solids (grey), wet solids (dark grey) 671 and DDGS (black), based on Osborne protocol

672

673

674

675 
676 Table 2. Protein content of isolates (\%,w/w) derived from DDGS and in-process 677 samples during different extraction conditions, as determined by Kjeldahl analysis

\begin{tabular}{|c|c|c|c|c|c|c|}
\hline & & & & \multicolumn{3}{|c|}{ Protein content of isolates $(\%, w / w)$} \\
\hline $\begin{array}{c}\text { Extraction } \\
\text { Temperature }\left({ }^{\circ} \mathbf{C}\right)\end{array}$ & $\begin{array}{c}\text { SMB } \\
(\%, w / w)\end{array}$ & $\begin{array}{c}\text { EtOH } \\
(\%, v / v)\end{array}$ & $\begin{array}{c}\mathrm{NaOH} \\
(\mathrm{M})\end{array}$ & DDGS & Wet solids & Spent solids \\
\hline \multirow{3}{*}{50} & 0.5 & & & $14.0(0.8)$ & $27.0(1.3)$ & $23.5(1.2)$ \\
\hline & 1.0 & 70 & - & $14.5(0.7)$ & $31.7(1.7)$ & $22.9(0.8)$ \\
\hline & 1.5 & & & $14.9(0.5)$ & $29.9(1.7)$ & $23.5(0.9)$ \\
\hline \multirow{3}{*}{70} & 0.5 & & & $34.1(3.2)$ & $47.8(2.9)$ & $53.6(2.8)$ \\
\hline & 1.0 & 70 & - & $42.7(2.1)$ & $55.6(2.9)$ & $62.4(0.5)$ \\
\hline & 1.5 & & & $44.9(1.5)$ & $58.2(0.5)$ & $54.7(0.3)$ \\
\hline \multirow{3}{*}{90} & 0.5 & & & $38.1(1.3)$ & $43.7(0.3)$ & $42.4(0.3)$ \\
\hline & 1.0 & 70 & - & $29.6(0.1)$ & $42.6(0.1)$ & $45.8(0.3)$ \\
\hline & 1.5 & & & $27.2(0.2)$ & $39.1(0.2)$ & $40.2(0.3)$ \\
\hline \multirow{3}{*}{70} & & 45 & 0.10 & $22.1(0.6)$ & $19.7(1.7)$ & $13.5(1.4)$ \\
\hline & 1.0 & 70 & 0.05 & $27.5(1.4)$ & $25.9(0.8)$ & $36.6(1.8)$ \\
\hline & & 70 & 0.10 & $39.5(2.1)$ & $49.1(0.7)$ & $51.8(2.2)$ \\
\hline
\end{tabular}

$678 \quad$ Data in parenthesis represent standard deviation values

679

680

681 


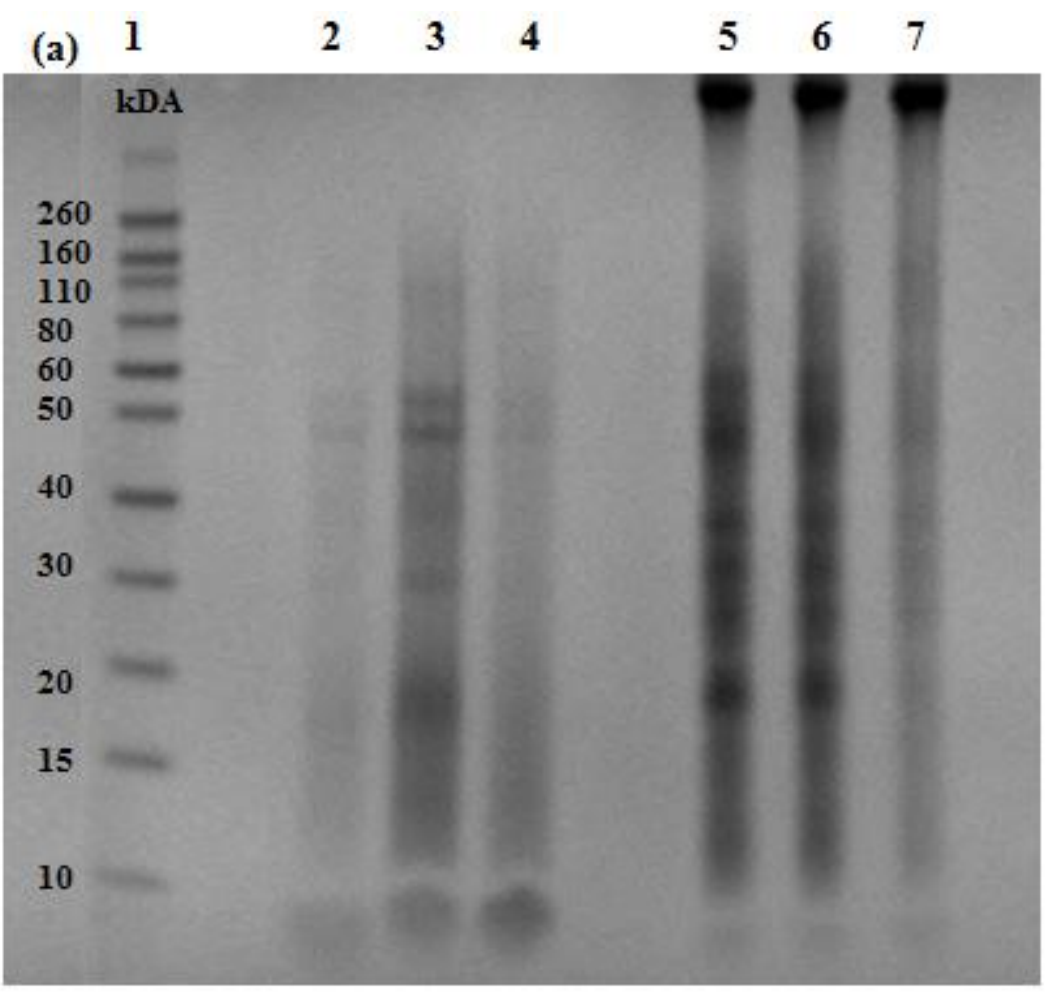

682

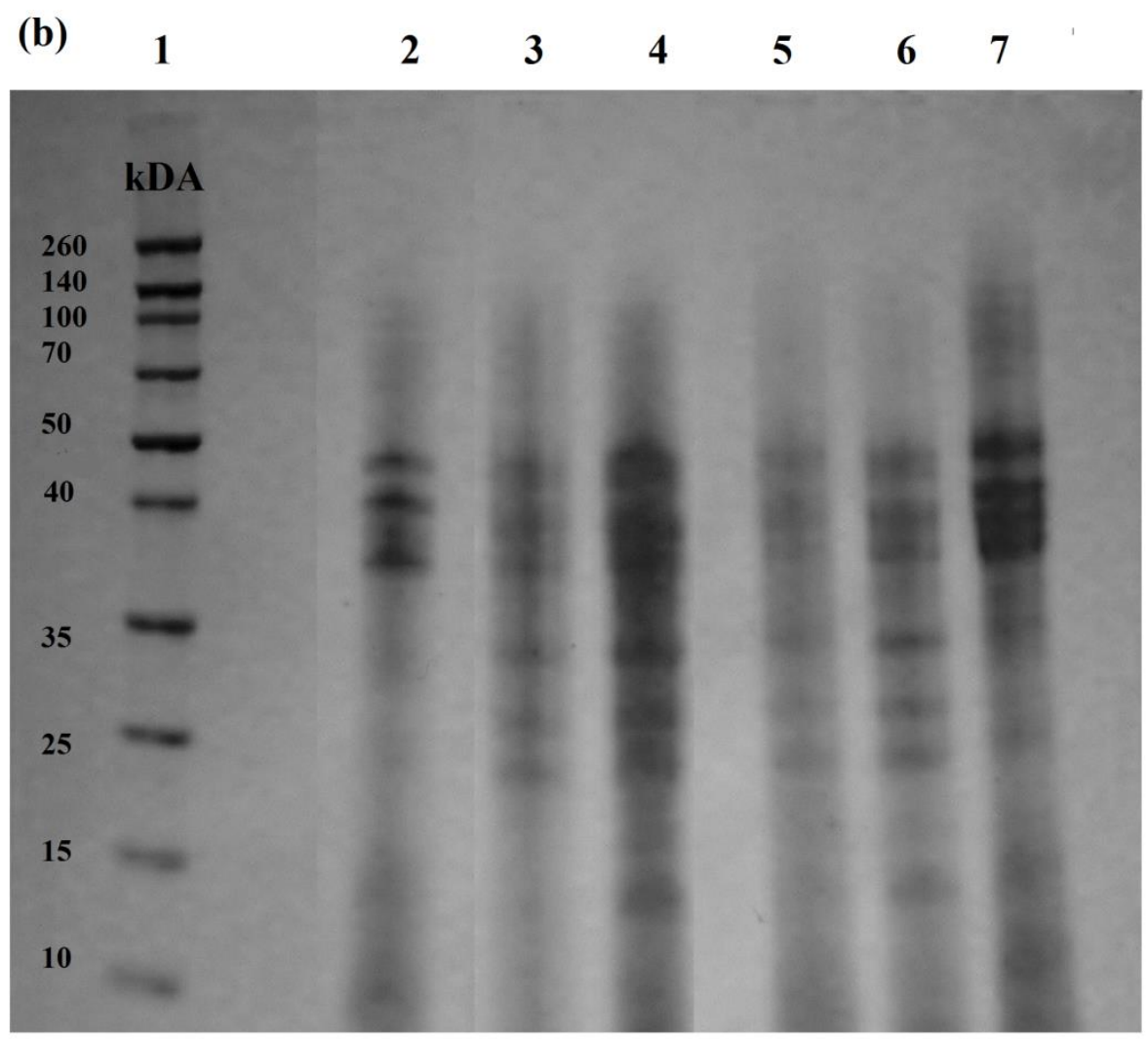

684 Fig 2. (a) SDS-PAGE according to the protocol by Singh et al. (1991) of original 685 samples: Lane 1, Molecular weight marker; lanes 2-4, Gliadin proteins of: spent solids 686 (lane 2), wet solids (lane 3) and DDGS (lane 4), respectively; Lanes 4-6, Glutenin 
687 proteins of: spent solids (lane 4), wet solids (lane 5) and DDGS (lane 6). (b) SDS688 PAGE of proteins extracted in aqueous-ethanol or alkaline-ethanol solutions: Lane 1, 689 Molecular weight marker; lanes 2-4, Ethanol extracted proteins of wet solids (lane 2), 690 spent solids (lane 3) and DDGS (lane 4); lanes 5-7, Alkaline (0.1M)-ethanol (70\%, $691 \mathrm{v} / \mathrm{v}$ ) extraction of wet solids (lane 5), spent solids (lane 6) and DDGS (lane 7). 692 
693 Table 3 Protein and carbohydrate content of ethanol extracted proteins and their solid 694 residues and mass balance calculations compared to the starting raw materials 695 (DDGS, wet solids, spent solids)

\begin{tabular}{|c|c|c|c|c|c|c|c|c|c|}
\hline & \multicolumn{3}{|c|}{ Protein extracts $(\%, \mathrm{db})$} & \multicolumn{3}{|c|}{ Solid residues $(\%, \mathrm{db})$} & \multicolumn{3}{|c|}{$\begin{array}{l}\text { Mass balance }^{\mathrm{b}} \\
(\%, \text { per } 100 \mathrm{~g})\end{array}$} \\
\hline & DDGS & $\begin{array}{c}\text { Wet } \\
\text { solids }\end{array}$ & $\begin{array}{l}\text { Spent } \\
\text { solids }\end{array}$ & DDGS & $\begin{array}{c}\text { Wet } \\
\text { solids }\end{array}$ & $\begin{array}{l}\text { Spent } \\
\text { solids }\end{array}$ & DDGS & $\begin{array}{c}\text { Wet } \\
\text { solids }\end{array}$ & $\begin{array}{l}\text { Spent } \\
\text { solids }\end{array}$ \\
\hline Protein $^{\mathrm{a}}$ & 44.7 & 55.6 & 62.4 & 11.6 & 7.4 & 4.7 & 68.7 & 89.2 & 92.8 \\
\hline Carbohydrates & 4.2 & 2.4 & 5.1 & 49.7 & 49.0 & 49.1 & 94.2 & 85.8 & 92.8 \\
\hline Glucose & 2.1 & 1.2 & 2.8 & 20.1 & 18.6 & 19.8 & 87.3 & 83.1 & 89.2 \\
\hline Xylose & 1.5 & 0.9 & 1.1 & 17.3 & 19.1 & 18.4 & 90.7 & 78.8 & 86.8 \\
\hline Arabinose & 0.6 & 0.3 & 1.1 & 12.3 & 11.3 & 10.9 & 101.8 & 92.6 & 108.9 \\
\hline
\end{tabular}

696 Data presented as mean values

697 a: Protein content measured by Kjeldahl

698 b: Mass balance for protein calculated by taking into account Osborne analysis results for gliadin and

699 glutenin content (45\% in spent solids, $78 \%$ in wet solids and $73 \%$ in DDGS).

700 


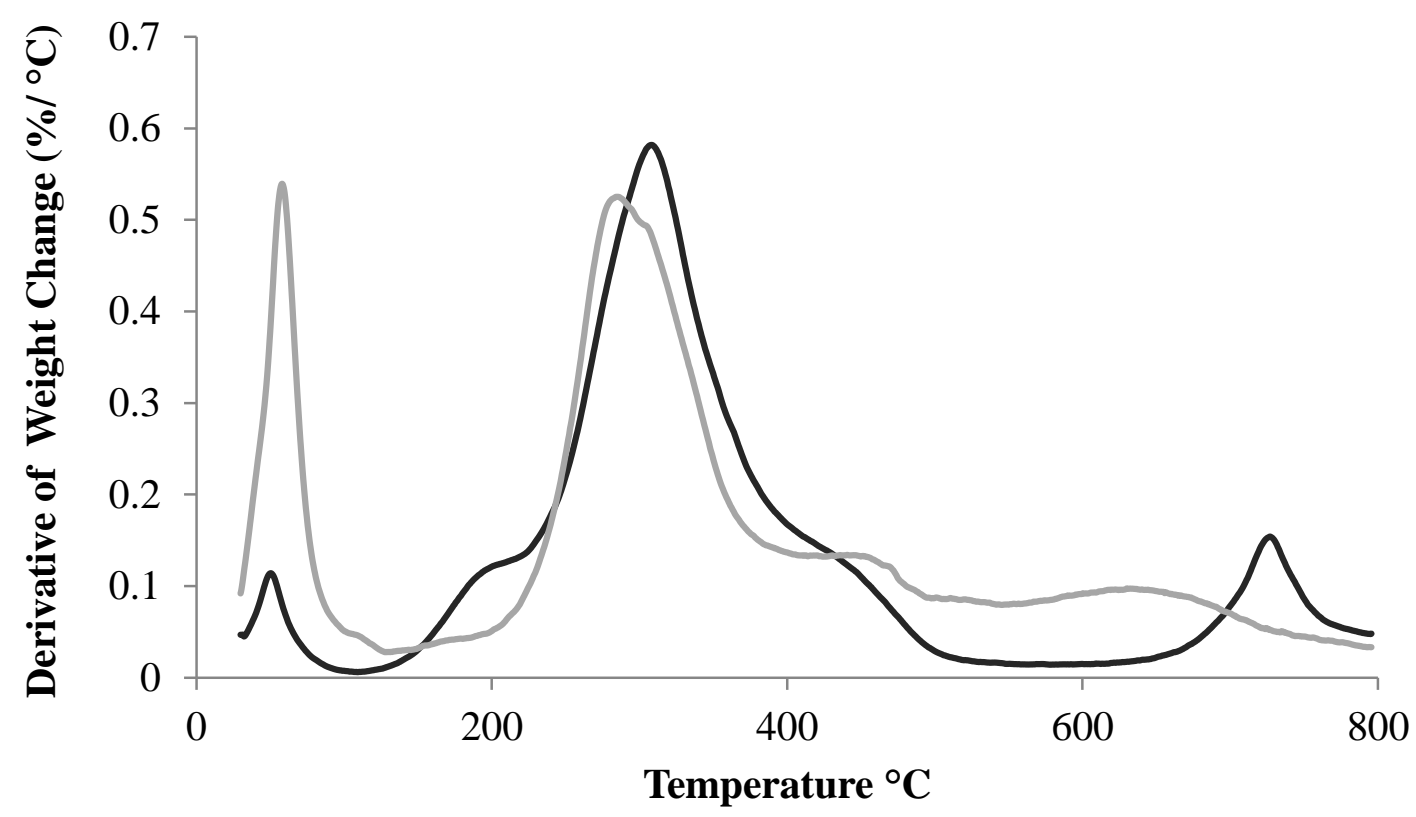

703

704 Fig 4. TGA analysis of ethanol extracted proteins from DDGS (black line) and wet 705 solids (grey line)

706 
(a)
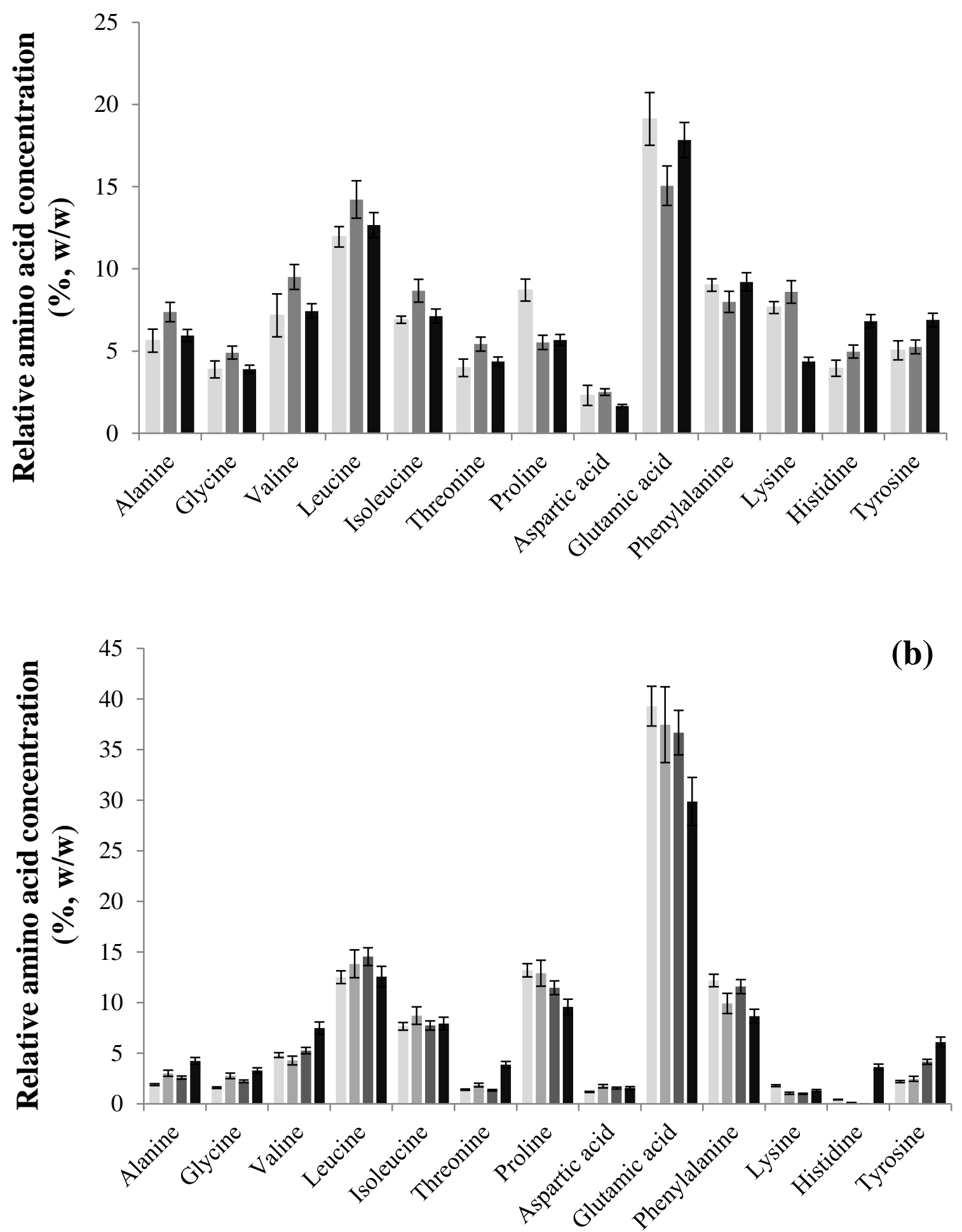

710 Fig 5. Amino acid analysis of samples: (a) Relative amino acid concentration of spent

711 solids (grey), wet solids (dark grey) and DDGS (black) after acid hydrolysis; (b)

712 Relative amino acid concentration in wet solid protein extracted with ethanol, (light

713 grey), wet solid protein extracted with alkaline-ethanol (grey), DDGS protein 
714 extracted with ethanol (dark grey) and DDGS protein extracted with alkaline-ethanol 715 (black). 